\title{
Presence of central nervous system tissues as bovine spongiform encephalopathy specified risk material in Turkish raw meat ball (cig kofte)
}

\author{
Ahmet Hulusi DİNÇOĞLU ${ }^{1 *}$
}

\begin{abstract}
Bovine Spongiform Encephalopathy (BSE) is a virulent disease which may infect by affecting the central nervous system (CNS) tissues in cattle and causes degeneration in nerves. Central nervous system tissues such as brain and spinal cord which are classified as specified risk materials (SRMs) are regarded to be main source of infection. The contamination of the meat with the specific risk materials (SRMs) can occur in phases of slaughter, fragmentation of carcass and processing. This study was conducted in order to investigate the existence of CNS tissues in raw meat ball (cig kofte) which is commonly consumed in the Southeastern Region of Turkey, particularly in Şanliurfa. For this purpose, 145 samples of raw meat ball were tested. The enzyme-linked immunosorbent assay (ELISA) kits (Ridascreen risk material 10/5, R-biofarm GmbH) which determine glial fibrillary acidic protein (GFAP) as determinant were used. As a result of the analyses, positivity was detected in 21 of totally 145 samples of raw meat ball (14.48\%). $6(4.14 \%)$ of the samples gave low level of positivity ( $\geq 0.1$ standard absorbance), 10 $(6.90 \%)$ gave medium level of positivity ( $>0.2$ standard absorbance) and 5 (3.45\%) gave high level of positivity $(\geq 0.5$ standard absorbance). As a consequence, meats are contaminated in any phase of both slaughter and meat production even if accidentally. Regarding this matter, necessary measures should be taken and hygiene rules should be applied.
\end{abstract}

Keywords: BSE; CNS tissues; ELISA; SRM; Turkish raw meat ball.

Practical Application: Researches to be done can prevent worldwide spread of the BSE by determining this tissue.

\section{Introduction}

"Transmissible Spongiform Encephalopathies (TSE)", encountered in animals and humans, is a chronic, degenerative, and virulent disease which affects the central nervous system and which causes an appearance in brain. These diseases are also called as "prion diseases" and no immunity emerges against the agent in patient (Fishbein, 1998; Godon \& Honstead, 1998; Kahraman et al., 2007). It has been stated that the agents causing TSE in humans and animals can pass through filters and are 100 times smaller than the smallest viruses. These agents are highly resistant to numerous physicochemical applications such as formaldehyde, $\beta$-propiolactone, proteases, nucleases and heat, to ionizing and ultraviolet radiation, to disinfectants which can normally inactivate viruses or bacteria (Godon \& Honstead, 1998).

"Bovine Spongiform Encephalopathy" (BSE=Mad Cow Disease) among these diseases has caused serious epidemics in cattle in England since 1986 and it has been reported to be transmitted to humans through meat and meat products obtained from cattle (Hedlin et al., 2012; Lee et al., 2013; Wells et al., 1987). Central Nervous System (CNS) tissues like brain and spinal cord considered as the specific risk material (SRM) are deemed as the main source of infection and constitute 95\% of the total infectivity (Scientific Steering Committee, 1999). It is reported that contaminated meat and bone flour added in dairy cattle feed are the source of the BSE disease for the cattle (Kale et al., 2006). Meat and meat-bone flour is forbidden to add to ruminant rations in Turkey according to Turkey legislations. There are some doubts about some farmers are still being added these products although it is forbidden. The infection could be prevented by increasing control measures and making more monitoring.

It was emphasized concerning transmission of the agent of mad cow disease to humans that the transmission can occur during eating of offals infected by BSE and fragmentation of meat in the slaughter house or butcher's shop or as a result of contamination of the meat by knives which have contacted to BSE infected spinal cord. It is reported that deaths have occurred among young people because of new variant-Creutzfeldt Jakob Disease (nvCJD) and among adult individuals because of Creutzfeldt Jakob Disease (CJD) depending on consumption of food infected by BSE in England and EU countries (Bauer et al., 1996; Buschmann et al., 2004; Hill et al., 1997).

Use of diseased cattle's meat, offals, and milk with high level of pathogen has been forbidden in human food chain because the health risk for humans consists of food products prepared from BSE infected cattle. England has been allowed to export meat to EU countries under these conditions. According to the Resolution of the EU Commission (Europe, 2000), testing of tissues and organs in head region of every animal slaughtered in slaughter houses became an obligation. Implementation of the communique of meat products (Turkey, 2000) disallowing 
the existence of CNS tissues in meat products in Turkey is inspected by veterinarians of the government in the official slaughter houses.

It is reported that detection of CNS tissues in meat (raw or cooked) and meat products (sausage, salami, fermented sausage etc) and tools and surfaces in the plants where they are processed is performed through kits with high sensitivity and commercial ELISA kits which are particularly developed for this purpose are used. The microplate wells in these kits are covered by polyclonal antibodies and reveal the existence of Neuron-Specific Enolase (NSE) or Glial Fibrillary Acidic Protein (GFAP) existing only in meat and meat products, contaminated materials, and standard liquids of the kits (Biofarm, 2001; Weyandt, 2001).

This study was conducted in order to investigate the existence of CNS tissues in raw meat ball which is commonly consumed in Turkey particularly in Eastern and the Southeastern Regions.

\section{Materials and methods}

\subsection{Collection and preparation of samples}

In this study, totally 145 samples of raw meat ball were tested in terms of the existence of CNS tissues. The samples of raw meat ball, which is commonly consumed especially in the region of Şanlıurfa in Turkey, were collected from restaurants within a period of 4 months between June and September. Samplings were realized by confirming the fact that bovine meat was added. Samples were collected from 13 enterprises (11 or 12 samples from each enterprise) performing production in this manner in different periods. Approximately $200 \mathrm{~g}$ of raw meat ball was collected in each sampling. The samples were homogenized by using a mixer before the phase of testing.

\subsection{Extraction of samples}

The extraction and the test steps were performed as defined by the commercial kit manufacturer. $10 \mathrm{ml}$ of extraction buffer was added in capped glass tube containing $2 \mathrm{~g}$ of homogenized sample, shaken thoroughly, and heated at $100^{\circ} \mathrm{C}$ for 15 minutes. It was centrifuged in $3500 \mathrm{rpm}$ at $10^{\circ} \mathrm{C}$ for 15 minutes after decreasing of heat. The fat layer at the top was removed by using pasteur pipette and then the remaining supernatant was diluted by buffer at $1 / 20$ ratio $(50 \mu \mathrm{L}$ of supernatant $+950 \mu \mathrm{L}$ of dilution buffer). The samples, which were extracted in daily basis, were stored at $-20^{\circ} \mathrm{C}$ until the test was performed.

\subsection{ELISA for meat samples}

The commercially available ELISA kit determining GFAP as marker (Ridascreen risk material 10/5, R-biofarm $\mathrm{GmbH}$ ) was used. The standard solution and the extracted sample of $50 \mu \mathrm{L}$ were distributed to wells by using pipette. Four standards ( $0 \%$, $0.1 \%, 0.2 \%$, and $0.5 \%$ ) were used as control. The test plates were mixed by being gently shaken after addition of conjugate of $50 \mu \mathrm{L}$ in each well and incubated for 30 minutes at room temperature. Addition of substrate/ chromogen (tetramethybenzidin) of $100 \mu \mathrm{L}$ followed the actions of washing three times with wash buffer, turning it down, and draining away its water by hitting. After shaking the plates gently, the second incubation was realized for 30 minutes at room temperature in dark environment. Then, stop solution of $100 \mu \mathrm{L}$ ( $1 \mathrm{~N}$ of sulphuric acid) was added in each well and optical densities were measured in $450 \mathrm{~nm}$ as three technical replicate.

\section{Results}

The average absorption values of each raw meat ball sample collected from 13 different enterprises were shown on Table 1. The optical density values of each sample was measured as three technical replicate, and standart deviations of averages was indicated next to average value of each sample (Table 1). All the absorbance values were obtained at the $450 \mathrm{~nm}$. The samples were assessed as positive when the absorbance of analyzed samples is equal to or higher than the absorbance of the standard of $0.1 \%$ for Ridascreen risk material $10 / 5$ as presented in the test procedure and 0.100 was considered as terminating value. As a result of these evaluations, no CNS tissue was detected in tested samples of three enterprises (Enterprise 8, 10 and 13), whereas it was detected in some samples of ten enterprises (Table 1). Totally, $21(14.48 \%)$ of whole 145 samples of raw meat ball were detected as positive (Tables 1 and 2). Six (4.14\%) of the samples gave low level of positivity ( $\geq 0.1$ standard absorbance), ten (6.90\%) gave medium level of positivity ( $>0.2$ standard absorbance)

Table 1. The summary results of absorption values for raw meat ball sample collected from 13 different enterprises.

\begin{tabular}{|c|c|c|c|c|c|}
\hline \multirow{2}{*}{ Enterprise } & \multirow{2}{*}{ Sample } & \multicolumn{4}{|c|}{ Ridascreen test kit standards (\%) } \\
\hline & & $\mathbf{0}$ & 0.1 & 0.2 & 0.5 \\
\hline \multirow{11}{*}{ Enterprise 1} & 1 & $0.001 \pm 0.0006$ & $0.010 \pm 0.0021$ & $0.018 \pm 0.0031$ & $0.035 \pm 0.0038$ \\
\hline & 2 & NTP & $0.001 \pm 0.0012$ & $0.004 \pm 0.0017$ & $0.012 \pm 0.0026$ \\
\hline & 3 & $0.005 \pm 0.0015$ & $0.058 \pm 0.0074$ & $0.117 \pm 0.0081$ & $0.214 \pm 0.0075$ \\
\hline & 4 & NTP & $0.002 \pm 0.0006$ & $0.006 \pm 0.0021$ & $0.012 \pm 0.0030$ \\
\hline & 5 & NTP & NTP & NTP & NTP \\
\hline & 6 & NTP & $0.003 \pm 0.0006$ & $0.006 \pm 0.0012$ & $0.013 \pm 0.0015$ \\
\hline & 7 & $0.011 \pm 0.0025$ & $0.088 \pm 0.0056$ & $0.203 \pm 0.0020$ & $0.366 \pm 0.0025$ \\
\hline & 8 & NTP & NTP & $0.002 \pm 0.0006$ & $0.002 \pm 0.0040$ \\
\hline & 9 & $0.002 \pm 0.0006$ & $0.020 \pm 0.0062$ & $0.037 \pm 0.0116$ & $0.060 \pm 0.0206$ \\
\hline & 10 & $0.008 \pm 0.0015$ & $0.094 \pm 0.0020$ & $0.207 \pm 0.0049$ & $0.351 \pm 0.0035$ \\
\hline & 11 & $0.020 \pm 0.0010$ & $0.115 \pm 0.0035$ & $0.188 \pm 0.0036$ & $0.380 \pm 0.0067$ \\
\hline
\end{tabular}


Table 1. Continued...

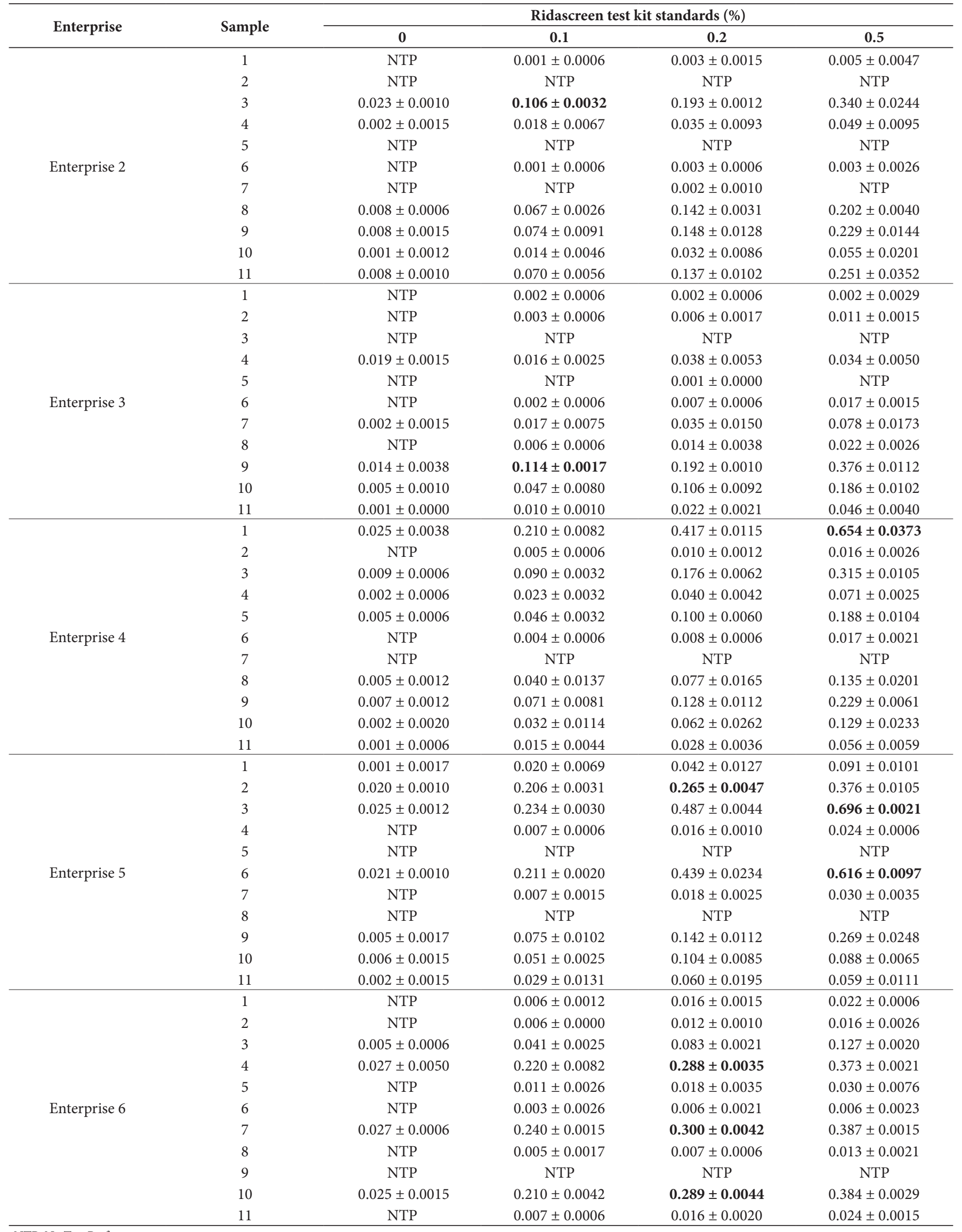

NTP: No Test Perform. 
Table 1. Continued...

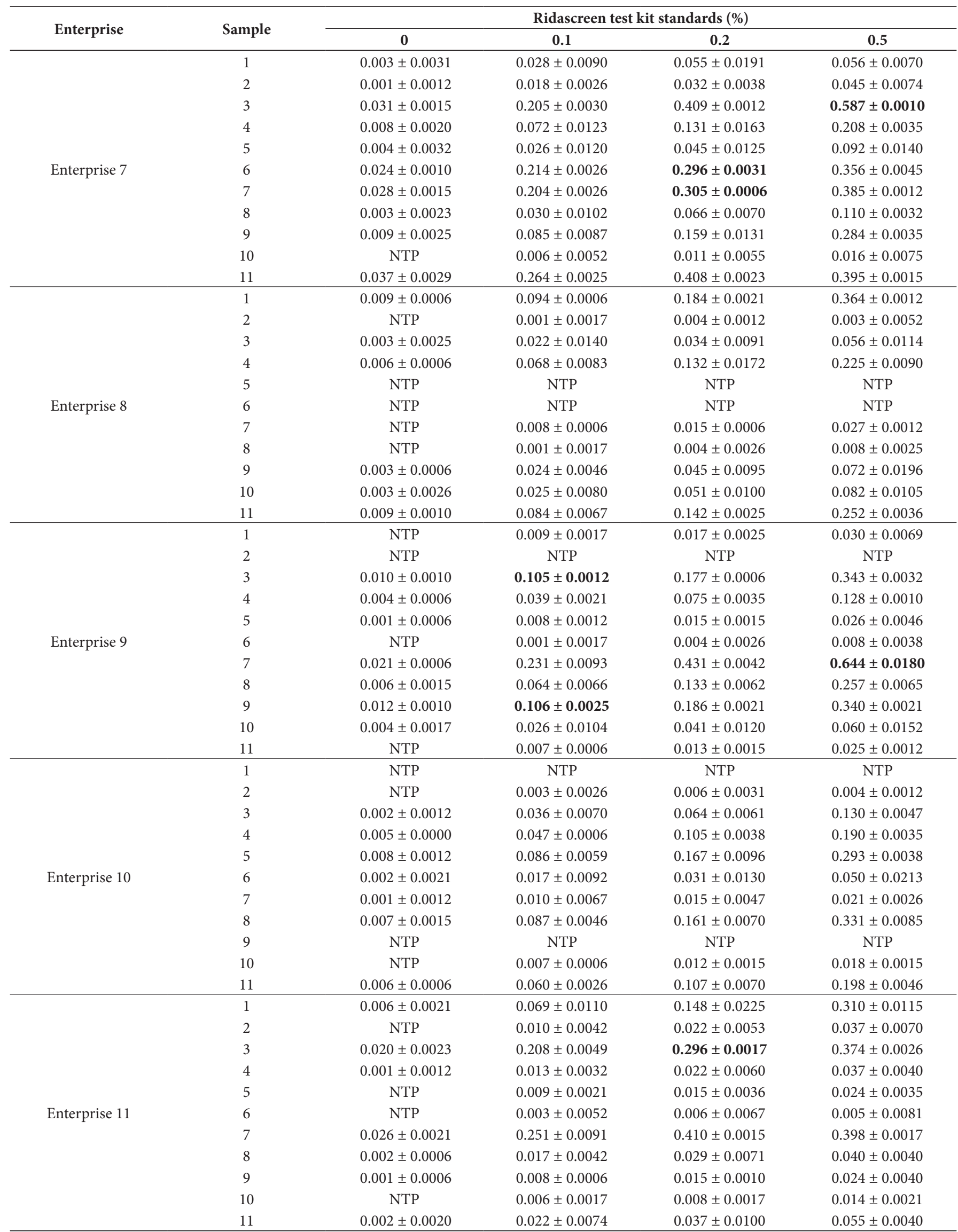

NTP: No Test Perform. 
Table 1. Continued...

\begin{tabular}{|c|c|c|c|c|c|}
\hline \multirow{2}{*}{ Enterprise } & \multirow{2}{*}{ Sample } & \multicolumn{4}{|c|}{ Ridascreen test kit standards (\%) } \\
\hline & & $\mathbf{0}$ & 0.1 & 0.2 & 0.5 \\
\hline \multirow{9}{*}{ Enterprise 12} & 1 & NTP & $0.007 \pm 0.0006$ & $0.013 \pm 0.0006$ & $0.027 \pm 0.0006$ \\
\hline & 2 & $0.017 \pm 0.0012$ & $0.137 \pm 0.0026$ & $0.183 \pm 0.0017$ & $0.319 \pm 0.0015$ \\
\hline & 4 & $0.006 \pm 0.0010$ & $0.067 \pm 0.0021$ & $0.115 \pm 0.0010$ & $0.188 \pm 0.0006$ \\
\hline & 5 & $0.025 \pm 0.0006$ & $0.243 \pm 0.0032$ & $0.321 \pm 0.0090$ & $0.385 \pm 0.0085$ \\
\hline & 8 & $0.001 \pm 0.0006$ & $0.008 \pm 0.0010$ & $0.014 \pm 0.0020$ & $0.022 \pm 0.0006$ \\
\hline & 9 & NTP & NTP & NTP & NTP \\
\hline & 10 & $0.004 \pm 0.0015$ & $0.041 \pm 0.0070$ & $0.076 \pm 0.0140$ & $0.143 \pm 0.0110$ \\
\hline & 11 & $0.007 \pm 0.0006$ & $0.075 \pm 0.0020$ & $0.137 \pm 0.0042$ & $0.216 \pm 0.0090$ \\
\hline & 12 & $0.002 \pm 0.0006$ & $0.027 \pm 0.0049$ & $0.044 \pm 0.0061$ & $0.085 \pm 0.0117$ \\
\hline \multirow{8}{*}{ Enterprise 13} & 5 & $0.002 \pm 0.0015$ & $0.015 \pm 0.0064$ & $0.026 \pm 0.0113$ & $0.047 \pm 0.0201$ \\
\hline & 6 & $0.001 \pm 0.0023$ & $0.021 \pm 0.0113$ & $0.037 \pm 0.0147$ & $0.078 \pm 0.0140$ \\
\hline & 7 & NTP & $0.006 \pm 0.0006$ & $0.011 \pm 0.0010$ & $0.018 \pm 0.0006$ \\
\hline & 8 & $0.002 \pm 0.0012$ & $0.019 \pm 0.0057$ & $0.028 \pm 0.0096$ & $0.047 \pm 0.0189$ \\
\hline & 9 & $0.001 \pm 0.0012$ & $0.017 \pm 0.0075$ & $0.022 \pm 0.0075$ & $0.034 \pm 0.0117$ \\
\hline & 10 & $0.001 \pm 0.0012$ & $0.017 \pm 0.0038$ & $0.028 \pm 0.0070$ & $0.050 \pm 0.0127$ \\
\hline & 11 & $0.004 \pm 0.0012$ & $0.040 \pm 0.0097$ & $0.069 \pm 0.0150$ & $0.121 \pm 0.0122$ \\
\hline & 12 & $0.001 \pm 0.0010$ & $0.013 \pm 0.0045$ & $0.022 \pm 0.0098$ & $0.032 \pm 0.0105$ \\
\hline
\end{tabular}

NTP: No Test Perform.

Table 2. Number and positivity rates of tested samples of raw meat ball.

\begin{tabular}{ll}
\hline \multicolumn{2}{c}{ Raw meat ball } \\
\hline Number of sample & 145 \\
Number of positive sample & $21(14.48 \%)$ \\
\hline
\end{tabular}

Table 3. Evaluation of positivity levels of positive samples by Ridascreen Risk Material 10/5 in terms of central nervous system tissues.

\begin{tabular}{cccc}
\hline Sample & $\begin{array}{c}\text { Number and } \\
\text { rate of positive } \\
\text { CNS samples } \\
(\%)\end{array}$ & Standards (\%) & Positivity level \\
\hline Raw meat ball & $6(4.14 \%)$ & $\geq 0.1$ & Low \\
& $10(6.90 \%)$ & $>0.2$ & Medium \\
& $5(3.45 \%)$ & $\geq 0.5$ & High \\
\hline
\end{tabular}

and five (3.45\%) gave high level of positivity ( $\geq 0.5$ standard absorbance). It was found that the highest level of positivity for CNS tissues in raw meat ball samples was the medium level $(>0.2)$ (Tables 1 and 3$)$.

\section{Discussion}

In diagnosis of BSE disease clinical symptoms are utilized in livestocks, whereas no finding is observed macroscopically in meat examination. The definitive result is based on detection of infective prion protein through special tests (Western-Blot, polyacrylamide gel electrophoresis, ELISA) in samples taken from brain and spinal cord tissue in dead animals. Diagnosis can be established also through histopathologic and electron microscope. The diagnosis established by using the method of feeding mice with samples of brain tissue taken from diseased cattle is not preferred because it requires a waiting period of 300 days in minimum (Buschmann et al., 2004; Godon \& Honstead, 1998; Levieux et al., 2001). Nowadays, it is reported that kits with high sensitivity and ELISA kits specifically developed for this purpose are used to determine tissues belonging to CNS in raw or cooked meat and meat products and in tools and surfaces in places where they are processed (Biofarm, 2001). European Union released a declaration concerning the totally exclusion of CNS tissues from meat products by the resolution of the Commission (Europe, 2000). The Communique of Meat Products of Turkish Food Regulation (Turkey, 2000) prohibits the mixture of CNS tissues with meat products.

Studies have been conducted to determine tissues of the risk material both in cattle meats and numerous products derived from these meats. However, there is no study in this direction on raw meat ball which is intensively consumed especially in eastern-southeastern region of Turkey and is produced by mixture of bovine meat.

In this study, the positivity in the samples of raw meat ball was detected at the rate of $14.48 \%$. Six of the analyzed samples (4.14\%) gave low level of positivity ( $\geq 0.1$ standard absorbance), $10(6.90 \%)$ gave medium level of positivity ( $>0.2$ standard absorbance), and 5 (3.45\%) gave high level of positivity 
( $\geq 0.5$ standard absorbance). In one of the studies conducted on raw meat materials in Turkey; Kale et al. (2007) determined the tissue of risk material in raw minced meat at the rate of $21.51 \%$ which is higher than our results. Furthermore, another researcher (Yeşilbağ \& Kalkan, 2005) found the positivity in 1 of the 43 samples (2.32\%) in the examinations performed on the same product. Nazlı et al. (2006) determined CNS tissue respectively in 3 (4\%) and 9 (12\%) of 75 samples of minced meat and 75 samples of small pieces of meat analyzed and obtained the results with lower values than our results. In a study examining raw and cooked meat samples (Kale et al., 2012), a low rate of positivity ( $\geq 0.1$ standard absorbance) was detected in $6(18.8 \%)$ of the 32 samples of raw meat ball.

Existence of CNS tissues in raw meat ball showed variability among enterprises. While CNS tissues were detected in raw meat ball samples of 10 enterprises, it was not detected in the samples of 3 enterprises. However, existence of CNS tissues in raw meat ball varied among samples even in the same enterprise based on collecting period. The results presented on Table 1 proved that meat ingredient used for production of raw meat ball is not identical even in the same enterprise. Therefore, this study indicated that meat ingredient of raw meat ball is not standardized at most enterprises. In addition, the results revealed that although adding CNS tissues into meat products is forbidden in Turkey, some enterprises sometimes mix CNS tissues with raw meat ball. Thus, inspection frequency of the enterprises should be increased to prevent mixture CNS tissues with raw meat ball in Şanliurfa, Turkey.

Some studies conducted by researchers from various countries on existence of CNS tissues in raw meat and carcasses (Blasche et al., 2012; Helps et al., 2002; Lücker et al., 2002, 2010; Schmidt et al., 2001; Weigel et al., 2010) revealed higher or lower values. These differences may be explained by the method used to determine the tissues of risk material, by the contamination of other tissues and organs with CNS tissues through the tools and equipments used especially in the phases of bisecting the carcasses in the slaughter houses and taking the spinal cord out, and by the density difference in this contamination. Additionally, the cross contaminations that the tools used in the phase of preparation of the product may cause should be taken into consideration in this sense. The contaminated equipments, surfaces, employees and carcasses are highly effective in contagion of specific risk materials (Prendergast et al., 2003). Tersteeg et al. (2002) reported that some processes performed during transformation of meat into the product could lead to chemical changes in reactive points of antigen. In this context, it can be thought that other additives added into mixture in the phase of production of raw meat ball may be effective on the detection of GFAP. However, for proof of this situation, it is required to conduct studies examining the effect of other substances added in ingredients of the product.

\section{Conclusion}

This study revealed the existence of CNS tissues in raw meat ball to which the meat was added without being subjected to any heat treatment. The obtained data have showed that the raw meat ball is a product group carrying risk in terms of BSE for consumers. More effective controls and measurements should be performed since the CNS tissues of cattle have risk in transmission of BSE agent from infected animals to humans and these should be performed and inspected by regulatory authorities. The companies operating in this subject should perform their own controls seriously in order to improve their quality levels. The results of this study indicated that the contamination of specific risk materials to food may be prevented through BSE tests to be performed in all private processing areas and slaughter houses and by controlling all other contamination instruments in Turkey.

\section{References}

Bauer, N. E., Garland, T., \& Edwards, J. F. (1996). Brain emboli in slaughtered cattle. Veterinary Pathology, 33(5), 600.

Biofarm. (2001). Instructions manual for Ridascreen ${ }^{\circledR}$ Risk Material Test. Germany: Biofarm.

Blasche, T., Schenck, E. V., Balachandran, A., Miller, M. W., Langenberg, J., Frölich, K., \& Steinbach, F. (2012). Rapid detection of CWD PrP: comparison of test designed for the detection of BSE or scrapie. Transboundary and Emerging Diseases, 59(5), 405-415. http://dx.doi. org/10.1111/j.1865-1682.2011.01294.x. PMid:22212828.

Buschmann, A., Biacabe, A. G., Ziegler, U., Bencsik, A., Madec, J. Y., Erhardt, G., Lühken, G., Baron, T., \& Groschup, M. H. (2004). Atypical scrapie cases in Germany and France are identified by discrepant reaction patterns in BSE rapid tests. Journal of Virological Methods, 117(1), 27-36. http://dx.doi.org/10.1016/j.jviromet.2003.11.017. PMid:15019257.

Europe. (2000). Commission Decision 2000/418/EC, 29 June 2000. Regulation the use of material presenting risk as regards transmissible spongiform encephalopathies and amending decision 94/747/EC. Official Journal of the European Communities (pp. 158/76).

Fishbein, L. (1998). Transmissible spongiform encephalopathies, hypotheses and food safety: an overview. The Science of the Total Environment, 217(1-2), 71-82. http://dx.doi.org/10.1016/S00489697(98)00164-8. PMid:9695172.

Godon, K. A. H., \& Honstead, J. (1998). Transmissible spongiform encephalopathies in food animals: human food safety and animal feed safety concerns for veterinarians. The Veterinary Clinics of North America, 14(1), 49-70. PMid:9532667.

Hedlin, P., Taschuk, R., Potter, A., Griebel, P., \& Napper, S. (2012). Detection and control of prion diseases in food animals. ISRN Veterinary Science, 2012, 1-24. http://dx.doi.org/10.5402/2012/254739. PMid:23738120.

Helps, C. R., Hindell, P., Hillman, T. J., Fisher, A. V., Anil, H., Knight, A. C., Whyte, R. T., O’Niell, D. H., Knowles, T. G., \& Harbour, D. A. (2002). Contamination of beef carcasses by spinal cord tissue during splitting. Food Control, 13(6-7), 417-423. http://dx.doi.org/10.1016/ S0956-7135(01)00040-8.

Hill, A. F., Desbruslais, M., Joiner, S., Sidle, K. C., Gowland, I., Collinge, J., Doey, I. J., \& Lantos, P. (1997). The same prion protein causes vCJD and BSE. Nature, 389(6650), 448-450, 526. http://dx.doi. org/10.1038/38925. PMid:9333232.

Kahraman, M. M., Ozygit, M. O., Akkoc, A., Ediz, B., Misirlioglu, D., Sonmez, G., Alasonyalilar, A., \& Yilmaz, R. (2007). Targeted surveliance to assess the presence of BSE in age risk population of cattle slaughtered in Bursa, Turkey: preliminary results of an immunohistochemical detection study for the 2004-2005 period. Journal of Veterinary Science, 8(2), 193-195. http://dx.doi.org/10.4142/ jvs.2007.8.2.193. PMid:17519575. 
Kale, M., Akcan Kale, A. S., Kurşun, Ö., Atasever, M., \& Başkaya, R. (2006). Et ve et ürünlerinde BSE-risk materyali var midır? Atatürk Üniversitesi Vet Bil Derg, 1(1-2), 16-19.

Kale, M., Hasırcioglu, S., Ozturk, C., Akcan Kale, A. S., \& Dogruer, Y. (2012). Detection of central nervous system tissue as bovine spongiform encephalopathy specified risk material in traditional Turkish meat products. Journal of the Science of Food and Agriculture, 92(8), 1653-1656. http://dx.doi.org/10.1002/jsfa.5527. PMid:22190149.

Kale, M., Kurşun, Ö., \& Pehlivanoğlu, F. (2007). Detection of central nervous system tissues as bovine spongiform encephalopathy specified risk material in processed and raw meat products in Turkey. Journal of Food Safety, 27(1), 56-65. http://dx.doi.org/10.1111/j.17454565.2007.00060.x.

Lee, J., Kim, S. Y., Hwang, K. J., Ju, Y. R., \& Woo, H. J. (2013). Prion diseases as transmissible zoonotic diseases. Osong Public Health and Research Perspectives, 4(1), 57-66. http://dx.doi.org/10.1016/j. phrp.2012.12.008. PMid:24159531.

Levieux, A., Rivera, V., \& Levieux, D. (2001). A sensitive ELISA for detection of bovine crude heparin in porcine heparin. Journal of Immunoassay \& Immunochemistry, 22(4), 323-336. http://dx.doi. org/10.1081/IAS-100107398. PMid:11816801.

Lücker, E., Biedermann, W., Alter, T., \& Hensel, A. (2010). GS/MS detection of central nervous tissue as specified BSE risk material in meat products and meat and bone meals: Thermal stability of markers in comparison with immunochemistry and RT-PCR'. Analytical and Bioanalytical Chemistry, 398(2), 963-972. http://dx.doi.org/10.1007/ s00216-010-3956-5. PMid:20625886.

Lücker, E., Schlottermuller, B., \& Martin, A. (2002). Studies on contamination of beef with tissues of central nervous system (CNS) as pertaining to slaughtering technology and human BSE-exposure risk. Berliner und Munchener Tierarztliche Wochenschrift, 115(3-4), 118-121. PMid:11938566.

Nazlı, B., Colak, H., Hampikyan, H., \& Bingöl, E. B. (2006). The presence of central nervous system tissues in meat products sold in İstanbul. Revue De Veterinaire, 157(12), 605-608.
Prendergast, D. M., Sheridan, J. J., Daly, D. J., McDowell, D. A., \& Blair, I. S. (2003). Dissemination of central nervous system tissue from brain and spinal cord of cattle after captive bolt stunning and carcass splitting. Meat Science, 65(4), 1201-1209. http://dx.doi.org/10.1016/ S0309-1740(03)00026-3. PMid:22063762.

Schmidt, G. R., Yemm, R. S., Childs, K. D., O’Callaghan, J. P., \& Hossner, K. L. (2001). The detection of central nervous system tissue on beef carcasses and in comminuted beef. Journal of Food Protection, 64(12), 2047-2052. PMid:11770636.

Scientific Steering Committee. (1999). Opinion on the human exposure risk (HER) via food with respect to BSE. Retrieved from http:// ec.europa.eu/food/fs/sc/ssc/out67_en.pdf

Tersteeg, M. H. G., Koolmees, P. A., \& Van Knapen, F. (2002). Immunohistochemical detection of brain tissue in heated meat products. Meat Science, 61(1), 67-72. http://dx.doi.org/10.1016/ S0309-1740(01)00164-4. PMid:22063915.

Turkey. (2000). TR 2000/4: türk gida yönetmeliği, et ürünleri tebliği. Resmi Gazete.

Weigel, I., Schulze, G., \& Pischetsrieder, M. (2010). Immunochemical detection of tissue from the central nervous system via myelin proteolitid protein: adaptation for food inspection and development of recombinant bivalent fab mini-antibodies. Journal of Agricultural and Food Chemistry, 58(11), 6587-6593. http://dx.doi.org/10.1021/ jf100625g. PMid:20476754.

Wells, G. A., Scott, A. C., Johnson, C. T., Gunning, R. F., Hancock, R. D., Jeffrey, M., Dawson, M., \& Bradley, R. (1987). A novel progressive spongiform encephalopathy in cattle. The Veterinary Record, 121(18), 419-420. http://dx.doi.org/10.1136/vr.121.18.419. PMid:3424605.

Weyandt, R. G. (2001). Detection of BSE-risk materials. Fresenius' Journal of Analytical Chemistry, 371(4), 574-575. http://dx.doi. org/10.1007/s002160101043. PMid:11760074.

Yeşilbağ, K., \& Kalkan, A. (2005). Detection of nervous system tissues as BSE specified risk material in meat products in Turkey. Food Control, 16(1), 11-13. http://dx.doi.org/10.1016/j.foodcont.2003.10.008. 